\title{
Comparison of structural and operational parameters of selected Euro VI engines used in long distance commercial vehicles
}

The article presents the most important technical solutions used in heavy duty diesel engines powering commercial vehicles - namely tractors - that meet the requirements of the Euro 6 norm. A comparative analysis of selected structural and operational parameters was also made on the example of engines with typical displacement close to $13 \mathrm{dm}^{3}$ used in long-distance tractors.

Key words: commercial vehicles, trucks, heavy duty diesel engines, Euro 6, engine parameters

\section{Porównanie parametrów konstrukcyjno-eksploatacyjnych wybranych silników Euro VI stosowanych w ciągnikach siodłowych}

$W$ artykule przedstawiono najważniejsze rozwiąania techniczne stosowane $w$ silnikach wysokoprężnych dużej mocy stosowanych do napędu ciagników siodłowych spetniających wymagania normy Euro 6. Dokonano również analizy porównawczej wybranych parametrów konstrukcyjno-eksploatacyjnych na przykładzie silników o pojemności skokowej zbliżonej do $13 \mathrm{dm}^{3}$ stosowanych w cianikach transportu dalekobieżnego.

Słowa kluczowe: pojazdy użytkowe, ciężarówki, silniki wysokoprężne dużej mocy, Euro 6, parametry silnika

\section{Introduction}

Having a closer look at the technical characteristics of the latest heavy duty engines (HDD) meeting Euro 6 standard, which are used in commercial vehicles, it can be easily seen that, despite assurances of the different OEMs about the individual and unique character of each solution, the overall concept of the engine, structure of exhaust aftertreatment systems, used technologies and precisely tailored design solutions seem to be very similar. Differences are, inter alia, type and quality of the materials used for the construction of individual components, the distribution of elements or control algorithms.

Typical for all constructions is increasingly common use of modern plastics, or composites. The performance of individual units or entire engine families have not changed significantly compared to the engines of previous generation, which frequently were the basis of new constructions. The main effort was to lower the fuel consumption of the engine and the whole truck, and thus, to help the vehicle owner to reduce the total cost of ownership and $\mathrm{CO}_{2}$ emissions [1].

The aim of the paper was to create a simplified technical analysis and comparison of Euro 6 engines. According to the author the most representative Euro 6 engine mounted on long haulage tractors will be a 6-cylinder, in-line diesel with a displacement of approx. $13 \mathrm{dm}^{3}$, offered with a number of performance levels (power and torque) such engines have in their portfolio all the major European manufacturers of commercial vehicles.

\section{The representative engine}

Typical 6-cylinder, in-line diesel with 13-liter displacement has a common-rail direct injection system, which reaches peak injection pressures between 2100 and 2500 bar (210-250 MPa). Injected fuel may be divided into several phases, such as, for example pilot, main and post injection. In some cases it may be up to 7 sequences - depending on the thermal conditions, rotational speed or power demand.

In the intake system, there will be a variable geometry turbocharger VGT, but it is not a rule. Mercedes-Benz OM 471 engine has a turbine with variable cross-section of the intake duct and the MAN D2676 engine has a two-stage turbocharging with two compressors with fixed geometry. Of course, each of the cylinders has 4 valves. Not only fresh air drawn in by the engine is compressed, but also exhaust gasses supplied by the EGR system, which were cooled beforehand in a heat exchanger. The recirculation (EGR) ratio varies depending on actual operating conditions [5].

At this point it is worth mentioning the solution proposed by Iveco. Cursor engines used to power heavy vehicles have so called Hi-eSCR system (i.e. highly efficient SCR) where exhaust gas recirculation has been completely abandoned. Also 9-liter Scania DC9 engines do without EGR, but they do not qualify for the review.

The purpose of the exhaust gas recirculation is to lower the maximum combustion temperature and thereby - reduce the amount of NOx produced during combustion of air-fuel mixture. Raw exhaust then enters a very sophisticated aftertreatment sys- 
tem, comprising usually of oxidation catalyst, particle filter DPF, urea (AdBlue) injection system, selective reduction catalyst SCR and ammonia slip catalyst [4].

Significant differences affecting the performance and durability of aftertreatment systems used by different brands may result from the construction of individual components, the type of materials used in their construction, final silencer configuration and applied control algorithms. No less important is the correct maintenance of the vehicle even in terms of quality of used fuel and periodic technical inspections. In this paper the author decided not to concentrate in detail on the aftertreatment systems.

It is worth to mention additional components, such as the throttle in the suction manifold which regulates the amount of intake air or the decompression engine brake. Change of the intake air quantity or recirculation ratio (regulated by EGR valve and VGT turbocharger) and engine braking effect influence the combustion process and change the exhaust temperature. This is the critical element in terms of the proper operation of the aftertreatment system. Some engines have an additional injector installed after the engine brake, which is used to supply low pressure fuel and air. Such mixture - if necessary - is injected into the exhaust manifold. Burned mixture increases the temperature of the exhaust gasses flowing to catalysts.

\section{Engine families}

The European heavy commercial vehicle market is divided between 7 major producers (OEMs). That are, in alphabetical order: DAF Trucks, Iveco, MAN Truck \& Bus, Mercedes Benz, Renault Trucks, Scania and Volvo Trucks. Every OEM offers long haulage Euro 6 tractors, correspondingly: DAF XF, Iveco Stralis Hi-Way, MAN TGX, Mercedes-Benz Actros, Renault T, Scania R Streamline, and Volvo FH. All trucks can be equipped with 13-liter engines belonging to the following families: Paccar (DAF) MX-13, Iveco Cursor 13, MAN D2676, Mercedes-Benz OM 471, Renault DTI 13, Scania DC13, Volvo D13K.

The following part of the paper shows a very short description of each engine family, pointing out the most important individual characteristics of each construction, that distinguish them from the competitive products. The most important technical parameters the reader will find in the included tables. The second part of the article presents the main features of the design and selection of parameters allowing for cross-referencing 13-litre engines with a rated power close to $368 \mathrm{~kW}$ (500 hp).

\subsection{DAF Paccar MX-13}

Paccar MX-13 Euro 6 engine is based on the American MX engine with a capacity of $12.9 \mathrm{dm}^{3}$, which meets the requirements of the US EPA 10 and is mounted in Kenworth and Peterbilt trucks. The engine block is made of cast iron with vermicular graphite. The installation on the engine block of two high-pressure fuel pumps increases the reliability and durability of the individual components. Pumps are driven by the same camshaft also integrated in the engine block (Fig. 1). Fuel from the main line is dispensed by electronically controlled valves that ensure optimum performance, by compression of actually needed amount of fuel.

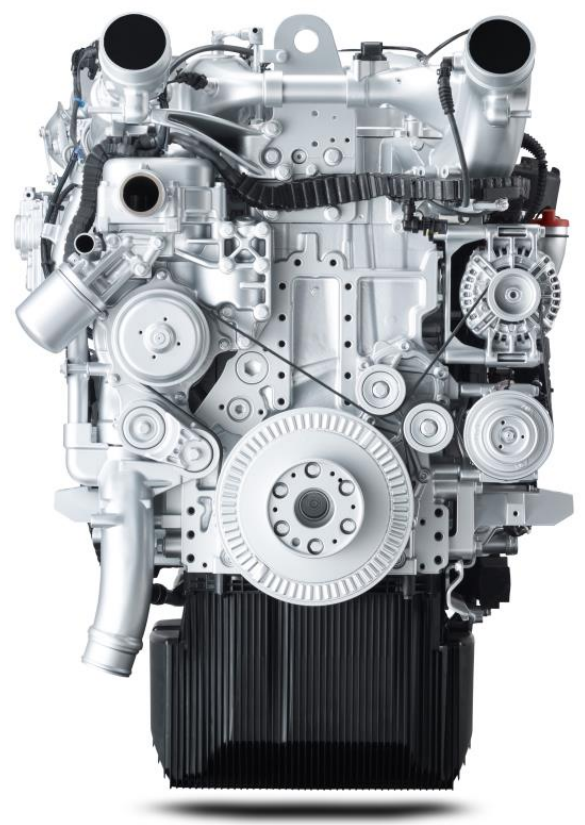

Fig. 1. A single belt and a fan that is mounted directly on the crankshaft without the use of intermediate shaft provide lower operating costs, improved reliability, and reduced vehicle weight and fuel consumption [11]

Rys. 1. Pojedynczy pasek wieloklinowy oraz wentylator, który jest zamontowany bezpośrednio na wale korbowym bez stosowania watu pośredniego zapewniaja niższe koszty eksploatacji, większa niezawodność, a także zmniejszenie masy pojazdu i zużycia paliwa [11]

The cooling fan is attached directly to the crankshaft, without unnecessary gear. Eliminating transmission mechanism reduced the costs and weight of the entire engine. Sump made of composite material is more spacious, lighter and reduces noise. Coolant pump has an electromagnetic clutch and can operate at two speeds, while the compressor fills the compressed air tanks to the maximum during the engine braking process, so that when driving on flat terrain it can be shut down [11].

\begin{tabular}{|c|c|c|c|}
\hline \multicolumn{4}{|c|}{ Paccar MX-13 Euro 6 } \\
\hline Max. power, kW/KM & $300 / 410$ & $340 / 460$ & $375 / 510$ \\
\hline at speed range, rpm & \multicolumn{3}{|c|}{$1450-1750$} \\
\hline Max. torque, Nm & 2000 & 2300 & 2500 \\
\hline at speed range, rpm & \multicolumn{3}{|c|}{$1000-1450$} \\
\hline
\end{tabular}




\subsection{Iveco Cursor 13}

Iveco developed its Cursor 13 Euro 6 engine together with FPT Industrial. Main focus was on reduction of NOx emissions and fuel consumption. To meet this assumptions, the exclusive use of SCR technology was introduced, with no EGR at all. Cursor 13 engine was equipped with common rail injection system, the maximum injection pressure reaches 2200 bar, and the injection can be divided into seven stages (pilot pre-injection, pilot injection, divided main injection, post-injection and late postinjection) [12].

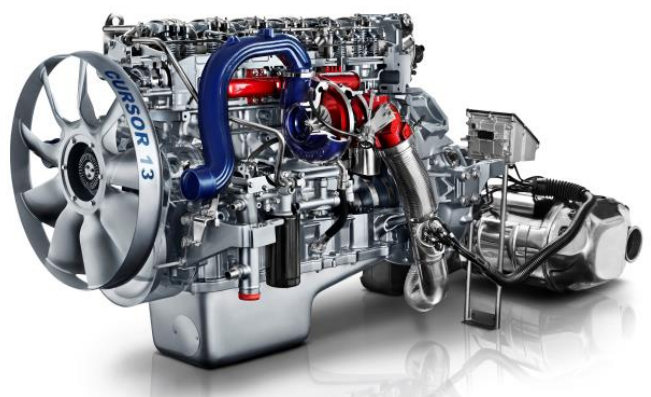

Fig. 2. Aftertreatment system Hi-eSCR made by FPT Industrial and used in Iveco Cursor 13 Euro 6 engines has no exhaust gas recirculation [12]

Rys. 2. W uktadzie oczyszczania spalin Hi-eSCR firmy FTP Industrial stosowanym w silnikach Cursor 13 Euro 6 calkowicie zrezygnowano z recyrkulacji spalin [12]

Iveco through optimized combustion conditions and the abandonment of the EGR system has reached so low emissions of toxic components in the raw exhaust gas that active regeneration of DPF filter, leading to increased fuel consumption, turned out to be unnecessary. In addition, engine supplied with the clean air has higher unit coefficients of power and torque, and is characterized by a more dynamic response to depressing the accelerator pedal. Not without significance is lower kerb weight of the vehicle.

Cursor 13 has a variable geometry turbocharger, the electronic control allows for better adjustment of charging conditions to the actual engine operating conditions. To facilitate the heating of the particle filter, electronically controlled throttle was introduced into the exhaust system, which in combination with exhaust flap increases engine braking power by $30 \%$.

\begin{tabular}{|c|c|c|}
\hline \multicolumn{3}{|c|}{ Iveco Cursor 13 Euro 6 } \\
\hline Max. power, kW/KM & $368 / 500$ & $412 / 560$ \\
\hline at speed range, rpm & $1500-1900$ & $1600-1900$ \\
\hline Max. torque, Nm & 2300 & 2500 \\
\hline at speed range, rpm & $900-1500$ & $1000-1600$ \\
\hline
\end{tabular}

\subsection{MAN D2676}

The basis for the new engines were tested structures of MAN D2676 Euro 5 engine, bore and stroke have not changed. Refined were such components as common rail injection system, cooling of EGR system, two-stage turbocharging, the SCR catalytic converter with integrated oxidation catalyst and diesel particulate filter CRT with continuous regeneration CRT. Common rail injection works with pressures up to 1800 bar [10].

The D2676 engine has two stage turbocharger, with intermediate and primary air cooling. Both stages have separate wastegate valves which control the boost pressure, allowing for full use of exhaust gas energy. High pressure stage (a small turbocharger), when the engine is running with less load and at lower rotational speeds generates boost pressure very quickly, what ensures high torque levels at low engine speeds. In contrast, a large, high performance turbocharger acting in the upper range of engine loads and speeds provides the necessary amount of air and has a very high coefficient of efficiency, resulting in very favourable fuel consumption and combustion with low level of particulate matter.

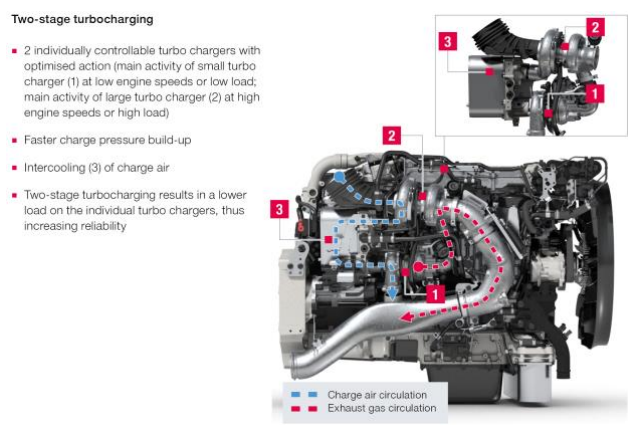

Fig. 3. Two-stage turbocharging in MAN D2676 engine: 1 - small turbocharger, 2 - big turbocharger, 3 - intercooler [10]

Rys. 3. Dwustopniowe doladowanie w silnikach MAN D2676: 1 - mała turbosprężarka, 2 - duża turbosprężarka, 3 - pośrednia chlodnica powietrza [10]
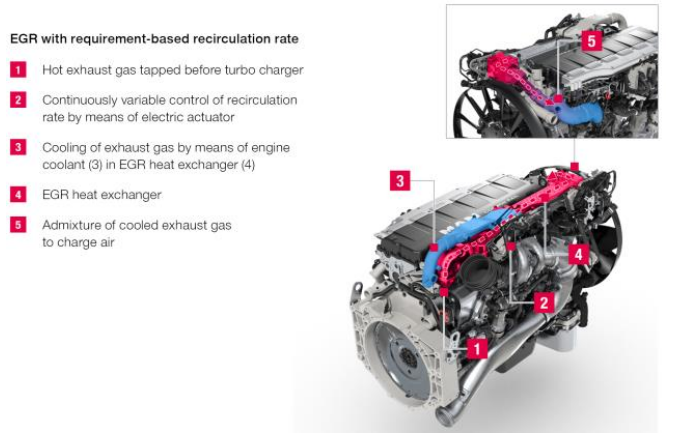

Fig. 4. In D2676 Euro 6 engines EGR rate is precisely controlled by electromagnetic actuator [10] Rys. 4. W silnikach D2676 stopień recyrkulacji spalin jest precyzyjnie kontrolowany przez silownik elektromagnetyczny [10]

\begin{tabular}{|c|c|c|}
\hline \multicolumn{2}{|c|}{ MAN D2676 Euro 6 } \\
\hline Max. power, kW/KM & $324 / 440$ & $353 / 480$ \\
\hline at speed range, rpm & \multicolumn{2}{|c|}{$1600-1900$} \\
\hline Max. torque, Nm & 2100 & 2300 \\
\hline at speed range, rpm & \multicolumn{2}{|c|}{$1050-1400$} \\
\hline
\end{tabular}




\subsection{Mercedes-Benz OM 471}

The latest generation of Mercedes-Benz engines, BlueEfficiency Power OM 471 has a crankcase made of a special patented alloy cast iron. Rigid monolithic cast cylinder heads were made of cast iron with graphite. Two camshafts are installed in the cylinder head with a hollow composite structure core. The cams are mounted there with negative allowance. One-piece pistons are made of steel - replacement of the aluminium helped to produce lower piston with a thinner coat [6].

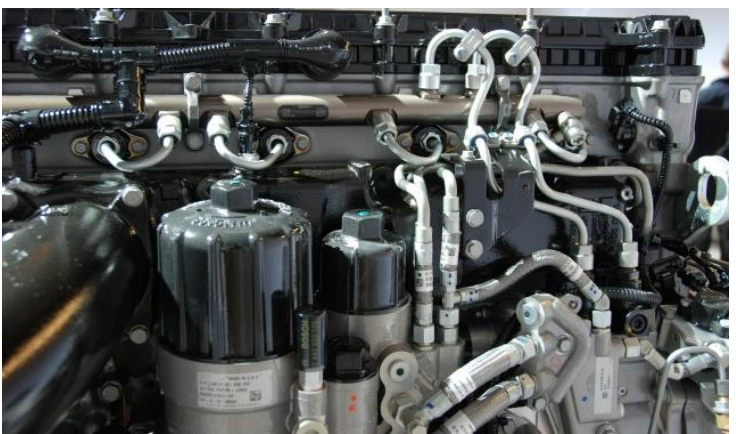

Fig. 5. X-Pulse system has two-piston high pressure fuel pump giving max pressure of 900 bar. This pressure is maintained in the fuel rail, hydraulic amplifiers in each of the injectors increase pressure up to 2100 bar [6]

Rys. 5. W systemie X-Pulse dwuttoczkowa pompa wysokiego ciśnienia wytwarza maksymalne ciśnienie na poziomie 900 bar, jest ono utrzymywane $w$ szynie paliwowej, wzmacniacze hydrauliczne $w$ każdym z wtryskiwaczy pozwalaja na zwiększenie ciśnienia do ok. 2100 bar [6]

OM 471 engine has X-Pulse common rail injection system. In the fuel rail maximum pressure reaches only approx. 900 bar and then is raised in the injectors by the hydraulic amplifiers up to the level of 2100 bar. X-Pulse for each cylinder individually adjusts the injection parameters depending on the operating conditions of the engine: injection timing, injection pressure, fuel dose, number of injections in one cycle.

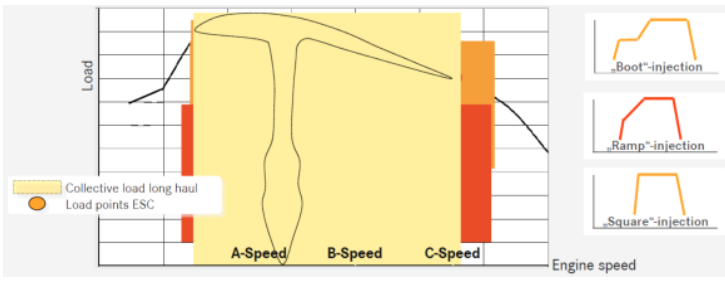

Fig. 6. X-Pulse system is capable of providing tailor-made injection strategies [6]

Rys. 6. Układ wtryskowy X-Pulse może realizować strategie wtrysku dopasowane do bieżacych warunków pracy silnika [6]

Fixed geometry turbocharger with asymmetric case is controlled by the wastegate. Three front cylinders are connected to the cooled EGR system. Exhaust gases from the other cylinders are directly routed to the turbine blades. When accelerating, the EGR valve is throttled so that a part of the exhaust gas reaches the turbine, which gives an effective response to depression of the accelerator pedal. As engine speed increases, the EGR valve opening increases, however, the pressure and flow of the exhaust gas entering the turbine from the cylinders allow for an adequate charging of the engine.

\begin{tabular}{|l|c|c|c|c|}
\hline \multicolumn{5}{|c|}{ MERCEDES-Benz OM 471 Euro 6 } \\
\hline $\begin{array}{l}\text { Max. power, } \\
\text { kW/KM }\end{array}$ & $310 / 420$ & $330 / 450$ & $350 / 480$ & $375 / 510$ \\
\hline at speed range, rpm & \multicolumn{4}{|c|}{1800} \\
\hline Max. torque, Nm & 2100 & 2200 & 2300 & 2500 \\
\hline at speed range, rpm & \multicolumn{5}{|c|}{$1000-1100$} \\
\hline
\end{tabular}

\subsection{Renault DTI 13}

Renault Trucks to create DXI 13 Euro 6 engines, used the proven, fuel efficient, Euro 5 units, but in the modernized engines more than $50 \%$ of the parts were redesigned and an all-new control driver was used. Moreover, the traditional cooled EGR system was abandoned.

Renault Trucks, to meet Euro 6 requirements like mother company Volvo Trucks - applied uncooled exhaust gas recirculation, which directs the hot exhaust directly into the intake manifold. Hot gases allow the engine and catalysts of the aftertreatment system to reach quickly operating temperature. Another way to increase the temperature is temporary closing of a flap valve, which is located between the intercooler and intake manifold [9].

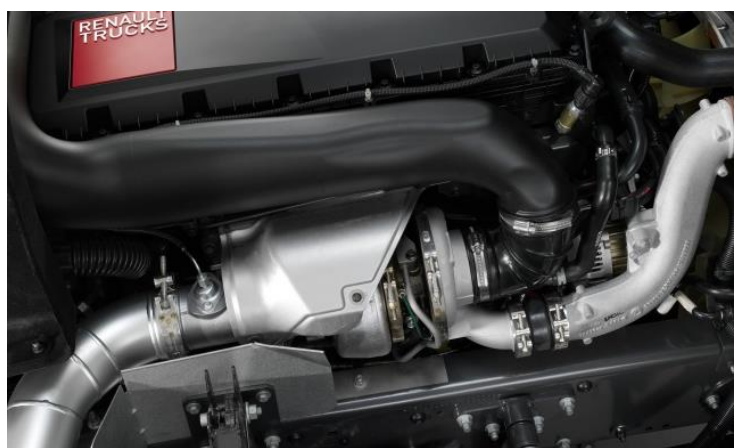

Fig. 7. If the engine operating conditions prevent proper operation of the SCR system and passive regeneration of the particulate filter, it is necessary to increase the temperature in a controlled way. This problem is solved by the seventh injector in the exhaust manifold and the flap valve downstream of the turbine [9]

Rys. 7. Jeśli warunki pracy silnika uniemożliwiaja prawidłowa pracę uktadu SCR oraz pasywna regeneracje filtra czastek stałych, niezbędny jest kontrolowany wzrost temperatury. Problem ten rozwiazuje siódmy wtryskiwacz $w$ kolektorze wydechowym $i$ zawór klapkowy za turbina [9] 


\begin{tabular}{|c|c|c|c|}
\hline \multicolumn{4}{|c|}{ Renault DTI 13 Euro 6 } \\
\hline Max. power, kW/KM & $323 / 440$ & $352 / 480$ & $382 / 520$ \\
\hline at speed range, rpm & \multicolumn{3}{|c|}{$1450-1900$} \\
\hline Max. torque, Nm & 2200 & 2400 & 2550 \\
\hline at speed range, rpm & $900-1400$ & $950-1400$ & $1000-1450$ \\
\hline
\end{tabular}

In the DTI 13 engine the fuel injection is done by the electronically controlled unit injectors - it was estimated that for the engine of this size, it is a sufficient solution and well proven in the Euro 5 units.

\subsection{Scania DC 13}

Construction of new Scania DC 13 Euro 6 engines is based on the modular engine platform, which uses many same components throughout the family of engines, making easier servicing and parts distribution. Each engine, independently of the design, the power and the fuel type, has steel pistons with a diameter of $130 \mathrm{~mm}$, a split, 4-valve cylinder head, the oil pan made of plastic, closed crankcase ventilation system and the cast iron engine block [7].

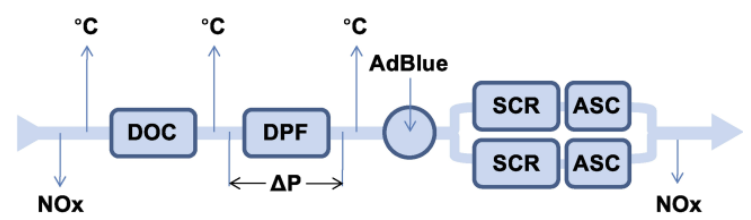

Fig. 8. Silencer of the Scania DC13 Euro 6 engine has integrated NOx sensor on the inlet side, diesel oxidation catalyst DOC, full flow diesel particle filter DPF, AdBlue mixer, parallel selective reduction catalysts SCR, unreacted ammonia catalyst ASC and NOx sensor on the outlet side. Exhaust temperature $\left({ }^{\circ} \mathrm{C}\right)$ is monitored at every stage of the process, the pressure drop $(\Delta \mathrm{P})$ in the DPF filter is also measured [7]

Rys. 8. W tlumiku silnika DC13 sa zintegrowane: czujnik NOx na wlocie, katalizator utleniajacy (DOC), petnoprzeplywowy filtr czastek statych $(D P F)$, mieszalnik AdBlue, równoległe katalizatory $S C R$, katalizator nieprzereagowanego amoniaku (ASC) oraz czujnik NOx na wylocie. Temperatura spalin $\left({ }^{\circ} \mathrm{C}\right)$ jest monitorowana na kazdym etapie procesu, mierzona jest równiez zmiana ciśnienia

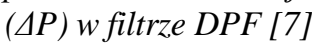

The DC 13 engine has Scania XPI multiphase common-rail fuel injection system, injecting fuel with medium pressure of 1800 bar and 8-hole injectors which can provide up to three doses in one cycle. In the intake system there is variable geometry turbocharger and an electronically controlled throttle valve which precisely regulates the amount of air reaching the combustion chamber. Throttling of the instantaneous air flow limits the filling of the cylinder, thus increasing the temperature.

\begin{tabular}{|l|c|c|c|c|}
\hline \multicolumn{5}{|c|}{ Scania DC 13 Euro 6 } \\
\hline $\begin{array}{l}\text { Max. power, } \\
\text { kW/KM }\end{array}$ & $272 / 370$ & $302 / 410$ & $331 / 450$ & $360 / 490$ \\
\hline at speed range, rpm & \multicolumn{4}{|c|}{1900} \\
\hline Max. torque, Nm & 1900 & 2150 & 2350 & 2550 \\
\hline at speed range, rpm & \multicolumn{5}{|c|}{$1000-1300$} \\
\hline
\end{tabular}

Scania recommends the choice of a slightly less powerful engine than in the case of Euro 5 units. The engine operated at higher loads, will be characterized by a higher temperature of the exhaust gas, and also, paradoxically, by lower fuel consumption. In order to maintain the correct temperature of the aftertreatment system, a small amount of fuel can be injected into the exhaust stream via a seventh injector. Similar task has a post-injection.

\subsection{Volvo D13K}

D13K engine is based on its predecessor D13A Euro 5. The most interesting solution in the new unit is the use of uncooled EGR system. Its main task is raising the temperature of the exhaust, when the combustion process is unable to produce enough heat necessary for the proper working of the SCR system. When driving at a cruising speed, EGR system in practice does not work, and thus does not increase fuel consumption. No cooling of exhaust gasses simplifies also the engine cooling system. Engine operation is supported by the VGT turbocharger, and therefore it was possible to significantly extend the range of engine speeds at which the maximum torque is obtained [8].

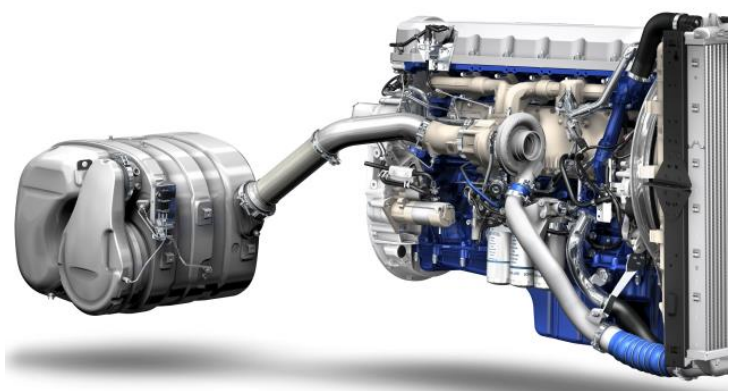

Fig. 9. In the D13K engine throttle behind the turbocharger, by regulating the exhaust flow controls the temperature, so that passive DPF regeneration is possible; if, still the temperature is too low, the seventh fuel injector supplies some fuel to start the active regeneration of the filter [8]

Rys. 9. W silniku D13K przepustnica za turbospręzarka, dtawiac przeptywu spalin reguluje temperature, tak aby możliwa była pasywna regeneracja filtra DPF; jeśli pomimo tego temperatura będzie zbyt niska, siódmy wtryskiwacz dostarczy porcję paliwa, rozpoczynajac aktywna regenerację filtra [8] 


\begin{tabular}{|l|c|c|c|c|}
\hline \multicolumn{5}{|c|}{ Volvo D13K Euro 6 } \\
\hline $\begin{array}{l}\text { Max. power, } \\
\mathrm{kW} / \mathrm{KM}\end{array}$ & $309 / 420$ & $338 / 460$ & $368 / 500$ & $397 / 540$ \\
\hline at speed range, rpm & \multicolumn{5}{|c|}{$1450-1850$} & $1450-1850$ \\
\hline Max. torque, Nm & 1900 & 2150 & 2350 & 2550 \\
\hline at speed range, rpm & \multicolumn{5}{|c|}{$1000-1300$} \\
\hline
\end{tabular}

The timing drive is on the back of the engine, take-off there (if necessary). The engine has an open crankcase ventilation with centrifugal oil mist separator. The D13K engine fuel injection system uses pump-injectors giving a maximum injection pressure up to 2000 bar. An additional injector in the exhaust manifold increases the exhaust gas temperature when it is necessary to regenerate the particulate filter. what reduces vibration and helps to mount power Table 1. Summary of main parameters and design features of the presented engines

\begin{tabular}{|c|c|c|c|c|c|c|c|}
\hline Engine & $\begin{array}{l}\text { Paccar } \\
\text { MX-13 }\end{array}$ & $\begin{array}{c}\text { Iveco } \\
\text { Cursor } 13 \\
\end{array}$ & $\begin{array}{l}\text { MAN } \\
\text { D2676 }\end{array}$ & $\begin{array}{l}\text { Mercedes } \\
\text { OM 471 }\end{array}$ & $\begin{array}{l}\text { Renault } \\
\text { DTI 13 }\end{array}$ & $\begin{array}{c}\text { Scania } \\
\text { DC13 }\end{array}$ & $\begin{array}{l}\text { Volvo } \\
\text { D13K }\end{array}$ \\
\hline Displacement, $\mathrm{dm}^{3}$ & 12,9 & 12,9 & 12,4 & 12,8 & 12,8 & 12,7 & 12,8 \\
\hline $\begin{array}{l}\text { Cylinder bore } \mathrm{D}, \\
\mathrm{mm}\end{array}$ & 130 & 135 & 126 & 132 & 131 & 130 & 131 \\
\hline Piston stroke $\mathrm{S}, \mathrm{mm}$ & 162 & 150 & 166 & 156 & 158 & 160 & 158 \\
\hline $\mathrm{D} / \mathrm{S}$ ratio & 0,80 & 0,90 & 0,76 & 0,85 & 0,83 & 0,81 & 0,83 \\
\hline $\begin{array}{l}\text { Compression } \\
\text { ratio }\end{array}$ & 17,0 & 16,5 & 18,0 & 17,3 & 17,0 & 17,3 & 17,0 \\
\hline $\begin{array}{l}\text { Maintenance } \\
\text { intervals, thous. km }\end{array}$ & 150 & 150 & 120 & 150 & 100 & 120 & 100 \\
\hline Camshaft & In block & SOHC & SOHC & DOHC & SOHC & In block & SOHC \\
\hline Cylinder head & \multicolumn{5}{|c|}{ Monolithic } & Split & Monolithic \\
\hline Turbocharging & VGT & VGT & 2-stage & asymethtric & VGT & VGT & VGT \\
\hline Injection system & $\mathrm{CR}$ & $\mathrm{CR}$ & $\mathrm{CR}$ & $\mathrm{CR}$ & PI & $\mathrm{CR}$ & PI \\
\hline $\begin{array}{l}\text { Max. injection } \\
\text { pressure, bar }\end{array}$ & 2500 & 2200 & 1800 & 2100 & 2000 & 2400 & 2000 \\
\hline EGR & Cooled & Not present & Cooled & Cooled & Uncooled & Cooled & Uncooled \\
\hline DPF regeneration & P-A-7I & $\mathrm{P}$ & P-A-PI & P-A-7I & P-A-7I & P-A-PI & P-A-7I \\
\hline
\end{tabular}

Table legend: VGT - variable geometry turbocharger, $\mathrm{CR}$ - common rail, $\mathrm{PI}$ - pump-injector, $\mathrm{P}$ - passive regeneration, $\mathrm{A}$ - active regeneration, $7 \mathrm{~W}-7^{\text {th }}$ injector in the exhaust manifold, $\mathrm{PW}-$ post injection (delayed injection)

\section{Engine benchmarks}

To determine the indicators of rotational speed flexibility, torque flexibility and total flexibility generally accepted formulas were used. For the clarity of the text they have been not included. In making the calculations the figures provided by the manufacturers were used, however it should be noted that they were not always given directly some of them (e.g. speed ranges of maximum power and torque) were taken from the graphs with the velocity characteristics of the engines, and these were not always accurate (table 1).

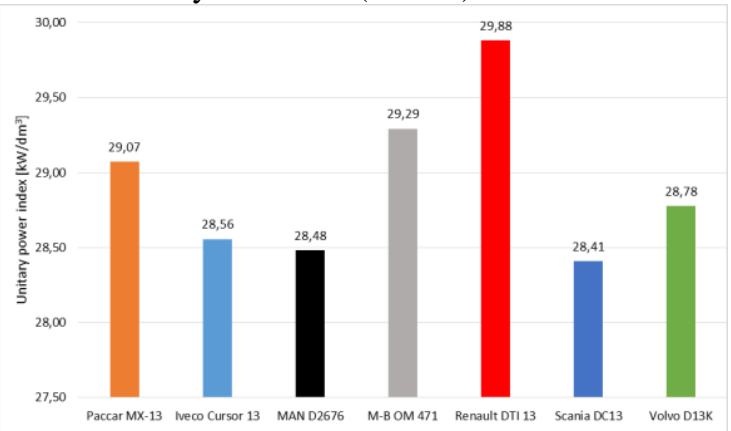

Fig. 10. Unitary power index Rys. 10. Moc jednostkowa
The presented tables show that all engines have a closely related indicators of the unit power (Figure 10) - the difference between the highest and the lowest is only $5.3 \%$. The differences stem from the fact that engines have different regulations: the weakest in the analysed group is MAN D2676 - 480 hp $(353 \mathrm{~kW})$, while the strongest Renault DTI 13 has $520 \mathrm{hp}(382 \mathrm{~kW})$. Much more interesting is the comparison of individual unitary torque indexes (Figure 11) - here the difference in the group is already $12.3 \%$. At the head of the pack is located Scania DC13 developing torque $2550 \mathrm{Nm}\left(200.8 \mathrm{Nm} / \mathrm{dm}^{3}\right)$, while the 500-hp Cursor 13 develops "only" 2300 $\mathrm{Nm}\left(178.3 \mathrm{Nm} / \mathrm{dm}^{3}\right)$, at the same time generating a power $10 \mathrm{hp}$ greater than Scania engine.

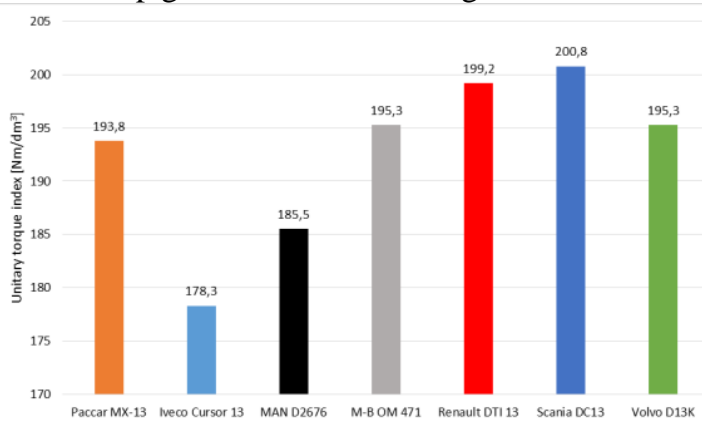

Fig. 11. Unitary torque index

Rys. 11. Moment jednostkowy 
All presented engines - except the MercedesBenz OM 471 - develop a maximum torque over a certain range of rotational speeds. In this regard, the best indicators has Cursor 13, maintaining maximum torque in the range from 900 to $1500 \mathrm{rev} / \mathrm{min}$. Undoubtedly, such a course of engine torque results mainly from the turbocharging characteristics in each of the engines. The variable geometry turbocharger has modified position of turbine blades, in order to fully utilize the exhaust energy, providing a constant value of the boost pressure, even when the engine is working with a relatively low speed. Twostage turbocharging used in MAN engine, apart from quick increase of inlet air pressure, provides also a constant pressure level, through the cooperation of smaller and larger turbines.

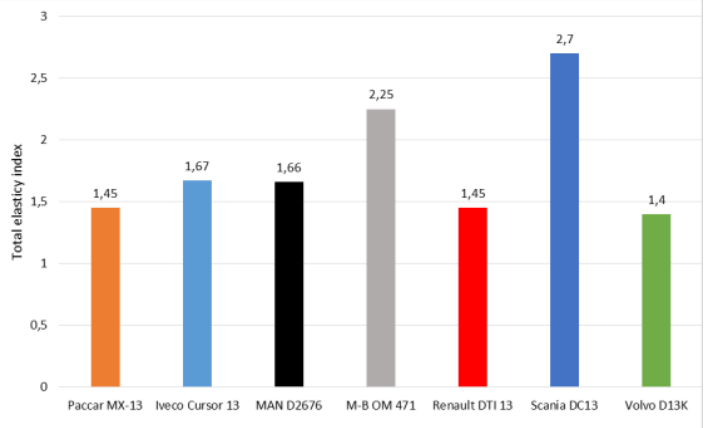

Fig. 12. Total flexibility coefficient Rys. 12. Wskaźnik elastyczności całkowitej

From the operational point of view, special attention deserve Scania and Mercedes - a major operational advantage of OM 471 and DC13 engines are high values of the coefficients of the total flexibility (Figure 12). When gear ratios in the gearbox, and in the final drive are properly selected, increase of the road resistance during the driving, does not enforce downshifting.

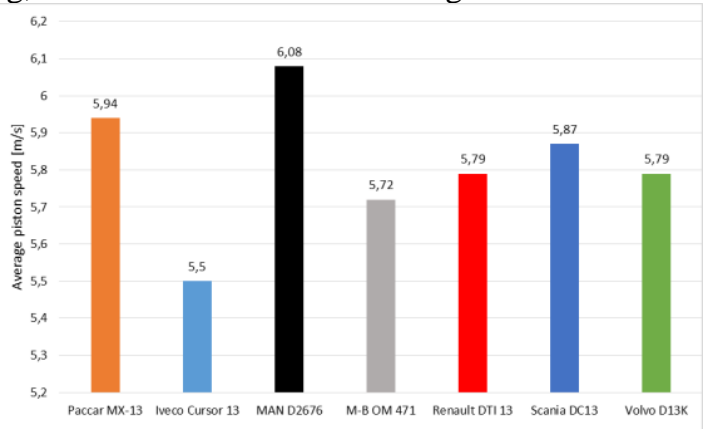

Fig. 13. Average piston speed

Rys. 13. Średnia prędkość tłoka

The average speed of the piston is one of the main factors determining the durability of the engine, in particular cylinder liner and piston rings. Its growth increases thermal and mechanical loads. To determine and compare average piston speeds of different engines, for the calculations typical rotational speed of the engine within the economical range was assumed, i.e. $\mathrm{n}=1100 \mathrm{rev} / \mathrm{min}$. At the assumed engine rotational speed the lowest average piston speed has Iveco Cursor 13 engine (Fig. 13). Basing only on this parameter it can be assumed that this engine should be - in comparison with the rest-less loaded. Of course, the quality and type of the materials used for the production of MAN D2676 engine, having the highest average piston velocity, can provide excellent durability in longterm use.

\section{Road tests}

If we decide to compare trucks or their engines, it is necessary always to remember that it is no longer only about the proverbial "nuts and bolts". A magic key-word can be used: modern, "smart" or high-tech technology. Also in case of a discussed in this paper comparison of seven Euro 6 engines one can analyse the innovative design solutions, usage of innovative materials or overall engine performance parameters including unitary ones. However, without the commercial vehicle - a truck, which is a carrier of the engine - even the most perfect automotive engine has no reason for being.

Therefore - in the comparison of Euro 6 engines given above, there is no "winner". The winner can only be a whole, complete vehicle. But also between trucks there are many significant differences, which does not allow to make a relatively objective evaluations. One can mention here such solutions as already used in some tractors shift algorithms using data provided by the cooperating topographic GPS systems or reducing fuel consumption coast-down functions (or so called eco-roll) or last but not least - an additional increase of torque and fast switching in the top gears. These and other truck features make any comparisons extremely difficult.

Of course there will be always attempts to objectify evaluations, an excellent example is a road evaluation test known as "The test of 1000 points" carried out by journalists from the German trucking magazines at the end of 2013 [2]. The test was done with typical tractor - trailer combinations with Euro 6 trucks supplied by DAF, MAN, Mercedes-Benz Scania and Volvo equipped with engines rated close to $460 \mathrm{hp} / 339 \mathrm{~kW}$ ( $\pm 20 \mathrm{KM} / 15 \mathrm{~kW})$. Trucks were evaluated in many ways, the assessed categories were: cab comfort and ergonomics, handling, performance, fuel and AdBlue consumption, productivity and safety.

The test mentioned above was won by the Mercedes-Benz Actros 1845 with Gigaspace cab. However, it is interesting to look closer at the results obtained by various vehicles in the category "performance", where attention was particularly paid to the engine characteristics. The highest rating was given to the Scania DC13 engine, but other diesels were rated almost as high. As for the fuel efficiency - the best results were obtained by the general winner - Mercedes-Benz Actros [3]. 
Is it possible to conclude that the results of "The Test of 1000 points" settle the problem which truck and which engine are the best? Of course not. Despite all efforts on repeatability and objectification of the test - it was only a press test.

\section{Summary}

One should not forget that market shares of a given OEM and popularity of the model is not determined only by the used technology. For the end user - truck owner - counts (in Poland still in a very high degree) the purchase price and, more generally speaking - the total cost of ownership of the vehicle.

\section{Nomenclature/Skróty i oznaczenia}

CRT Continously Regenerating Trap / filtr cząstek stałych o regenracji ciagłej

DPF Diesel Particulate Filter / filtr czastek stałych

EGR Exhaust Gas Recirculation / recyrkulacja spalin

OEM Oryginal Equipment Manufacturer / producent końcowy

\section{Bibliography/Literatura}

[1] Hoepke E., Breuer S.: Das große Buch der LKW-Technik. Motorbuchverlach 2010.

[2] 1000 points test. "Commercial Motor", no $2 / 1 / 2014$.

[3] Zeitzen F.: Internationales Euro 6-Treffen. "lastauto omnibus", no 1/2014.

[4] Euro 6. The inside story. "Commercial Vehicle Engineer", no 03/2013.

[5] Beyond Euro 6. "Transport Engineer", no 12/2013.

Mr Piernikarski Dariusz, DSc., M.Sc.Eng. Doctor in the Faculty of Mechanical Engineering at Lublin University of Technology.

Dr inż. Dariusz Piernikarski - adiunkt na Wydziale Mechanicznym Politechniki Lubelskiej.
Another important factor is the level of service and pre- and aftersales, especially in the area of financing possibilities, service network density, and scope and cost of the maintenance contracts.

Finally, it is the driver behind the wheel having a modern Euro 6 tractor or chassis, who must be an excellent specialist. In the end it all depends on him: he has an impact on fuel consumption, durability and reliability of the vehicle. Finding such a person becomes more and more difficult. Even the most modern technology on board without the participation of a good, conscious driver is almost useless.

SCR Selective Catalytic Reduction / selektywna redukcja katalityczna

VGT Variable Geometry Turbine / turbosprężarka o zmiennej geometrii
[6] Böckenhoff E.: Press presentation "Innovation meets Production. Mercedes-Benz, 03/2011.

[7] Scania press info, P11301PL, 03/2011.

[8] Volvo Trucks press information, 09/2012.

[9] Renault Trucks, informacja prasowa, 05/2013.

[10] MAN Truck \& Bus, informacja prasowa, 04/2013.

[11] Kołodziejek Z.: Prezentacja prasowa „DAF XF Euro 6", 03/2013.

[12] Iveco, press relase, 20120701, 07/2012. 